Portland State University

PDXScholar

Political Science Faculty Publications and

Presentations

Political Science

6-13-2019

\title{
Do Female Local Councilors Improve Women's Representation?
}

Lindsay J. Benstead

Portland State University, benstead@pdx.edu

Follow this and additional works at: https://pdxscholar.library.pdx.edu/polisci_fac

Part of the Comparative Politics Commons

Let us know how access to this document benefits you.

\section{Citation Details}

Published as: Benstead, L. J. (2019). Do Female Local Councilors Improve Women's Representation?. The Journal of the Middle East and Africa, 1-25.

This Post-Print is brought to you for free and open access. It has been accepted for inclusion in Political Science Faculty Publications and Presentations by an authorized administrator of PDXScholar. Please contact us if we can make this document more accessible: pdxscholar@pdx.edu. 


\title{
Do Female Local Councilors Improve Women's Representation?
}

\author{
Lindsay J. Benstead* \\ Associate Professor, Mark O. Hatfield School of Government, Department of Political Science, \\ Portland State University \\ (benstead@pdx.edu; Address: 506 SW Mill Street, Portland, OR 97201; Phone: 503-725-8278;
}

ORCID 0000-0003-2459-5857)

\author{
Scholar, Woodrow Wilson International Center for Scholars \\ Washington, DC
}

Forthcoming in the Journal of Middle East and Africa.

*The author gratefully acknowledges the Program on Governance and Local Development (GLD), Yale University, the Moulay Hicham Foundation, and the World Bank for funding the 2015 Tunisian Local Governance Performance Index (LGPI) Survey. I thank Ellen Lust, Pierre Landry, and Dhafer Malouche for collaborating on the Tunisian LGPI and the Association for the Study of the Middle East and Africa (ASMEA) and Portland State University for funding the presentation of an earlier version of this paper at the Association for the Study of Middle East and North Africa (ASMEA), Washington, DC, October 19-21, 2017 and the annual conference of the Midwest Political Science Association, Chicago, IL, April 7-10, 2016. Specials thanks to Ellen Lust, Amanda Clayton, and attendees of the EGEN meeting, Vanderbilt University, Nashville, TN, May 4-5, 2018 for helpful comments.

Biographical note

Lindsay J. Benstead is Director of the Middle East Studies Center (MESC) and Associate Professor of Political Science in the Mark O. Hatfield School of Government at Portland State University. She is a currently a Global Fellow at the Woodrow Wilson International Center for Scholars in Washington, DC and has previously served as Kuwait Visiting Professor at SciencesPo, Paris. She holds a Ph.D. in Public Policy and Political Science from the University of Michigan in Ann Arbor and served as a doctoral fellow at Yale University and a post-doctoral fellow at Princeton University.

Funding details

The 2015 Tunisian Local Governance Performance Index (LGPI) Survey was supported by the Program on Governance and Local Development (GLD), Yale University, the Moulay Hicham Foundation, and the World Bank. Preparation of this article was supported by the Association for the Study of the Middle East and Africa (ASMEA) and the Woodrow Wilson International Center for Scholars.

Disclosure statement

I do not have any conflict of interest, real or perceived, arising from this research. 


\begin{abstract}
Tunisia's 2018 municipal elections, in which a legislated quota was implemented and women won 47 percent of seats, raises questions about whether electing female councilors improves women's representation in clientelistic settings. Using data from the Local Governance Performance Index (LGPI), an original survey of 3,600 Tunisians conducted in 2015 by the Program on Governance and Local Development (GLD), this paper investigates the relationship between local councilors' gender and women's access to help with personal or community issues. Three findings emerge. First, male citizens are thirteen percentage points more likely to know a local councilor and six percentage points more likely to have contacted a councilor for help. Second, citizens of both genders are twice as likely to contact a councilor of the same gender when asking for help with community problems. Finally, electing females increases women's access to councilors, due to network homosociality— that is, denser personal networks with others of the same gender-but has a limited impact on men's access because female councilors have more hetersocial networks. By showing that electing and appointing women improves service and allocation responsiveness to females, the results call attention to the need to address gender equity issues when drafting electoral laws and implementing decentralization laws.
\end{abstract}

Keywords: Local councils, women's representation, service provision, Middle East and North Africa, Tunisia 
In 2018, seven years after the Arab uprisings, Tunisia held municipal elections, the first since the revolution that ousted former President Ben Ali in 2011. In response to the 2014 constitutional provision, which commits the state to promoting gender parity in elected assemblies (Article 10), the 2018 municipal election law included a gender quota establishing vertical and horizontal parity for women on party lists in the country's closed-list proportional representation (PR) electoral system. As a result, women won forty-seven percent of seats in local councils in May 2018.

Tunisia first implemented a gender quota at the national, regional, and local levels under Ben Ali, when the dominant ruling Constitutional Rally for Democracy (RCD) party occupied most seats in the nation's assemblies. Nationally, women won twenty-three percent of seats in parliament in 2004, and the number rose to twenty-eight percent in 2009. Locally, women won twenty-seven percent of seats in the 2010 municipal elections. ${ }^{1}$ Following the revolution that same year, a legislated quota was implemented for the country's first free and fair elections to the Constituent Assembly. These elections resulted in twenty-eight percent of seats in 2011 and thirty-one percent in 2014 for women in the first two parliaments. ${ }^{2}$

\footnotetext{
${ }^{1}$ Estimates vary. One report estimates women made up 33.6 percent of local council seats following the 2010 municipal elections Clement M. Henry, "Countries at the Crossroads 2011: Tunisia" (Freedom House), accessed November 11, 2018, https://freedomhouse.org/sites/default/files/inline_images/TUNISIAfinal.pdf.

${ }^{2}$ Lindsay J. Benstead, “Tunisia," in Global Handbook on Women's Political Rights, ed. Susan Franceschet, Mona Lena Krook, and Netina Tan, 2019.
} 
Yet, despite the strong role women play in Tunisia's local governments, little is known about how women's presence affects service and allocation responsiveness to females. Are women more able to ask for personal services and community needs when more women hold office? This question is an important one, due to the importance of informal networks for accessing individual and public services in clientelistic settings with weak local councils, as is the case in Tunisia.

Most literature examining the impact of quotas on substantive representation of women focuses on national parliaments. ${ }^{3}$ Studies of local and regional governance have been more limited than national-level studies, due to the difficulty of collecting local-level data, such as the

${ }^{3}$ See, e.g., Lindsay J. Benstead, "Why Quotas Are Needed to Improve Women's Access to Services in Clientelistic Regimes," Governance 29, no. 2 (2016): 185-205, https://doi.org/10.1111/gove.12162; Lindsay J. Benstead, Amaney A. Jamal, and Ellen Lust, "Is It Gender, Religiosity or Both? A Role Congruity Theory of Candidate Electability in Transitional Tunisia" 13, no. 1 (2015): 74-94, https://doi.org/10.1017/S1537592714003144; Susan Franceschet and Jennifer M. Piscopo, “Gender Quotas and Women's Substantive Representation: Lessons from Argentina," Politics \& Gender 4, no. 3 (2008): 393-425, https://doi.org/10.1017/S1743923X08000342. 
gender makeup of local councils. But, an increasing number of studies of India, ${ }^{4}$ Lesotho, ${ }^{5}$ and other countries examine women's representation at the local level. Several studies find a positive impact on women's representation. In India, female local council heads were more responsive to women's requests, including help with police corruption and landlord exploitation, and requests sometimes influenced policymaking. ${ }^{6}$ Chattopadhyay and Duflo showed that provision of public goods that are important to women, such as nearby drinking water, was higher in Indian districts headed by females. ${ }^{7}$ Similarly, Beaman, Chattopadhyay, Duflo, Pande, and Topalova found that citizens living in districts with female-headed local councils were less likely to exhibit hostile sexism and more likely to support women as political leaders, a form of symbolic

\footnotetext{
${ }^{4}$ Rohini Pande, "Can Informed Voters Enforce Better Governance? Experiments in Low-Income Democracies" 3, no. 1 (2011): 215-237, https://doi.org/10.1146/annurev-economics-061109-
} 080154.

${ }^{5}$ Amanda Clayton, "Electoral Gender Quotas and Attitudes toward Traditional Leaders: A Policy Experiment in Lesotho," Journal of Policy Analysis and Management 33, no. 4 (2014): 10071026, https://doi.org/10.1002/pam.21789.

${ }^{6}$ Neema Kudva, "Engineering Elections: The Experiences of Women in Panchayati Raj in Karnataka, India," International Journal of Politics, Culture, and Society 16, no. 3 (2003): 445 463, https://doi.org/10.1023/A:1022312613488.

${ }^{7}$ Raghabendra Chattopadhyay and Esther Duflo, "Women as Policy Makers: Evidence from a Randomized Policy Experiment in India,” Econometrica 72, no. 5 (2004): 1409-43. 
representation. ${ }^{8}$ Yet, Clayton finds that local quotas have either no effect or a negative effect on women's political engagement in Lesotho. ${ }^{9}$

To assess the substantive (i.e., service, allocation, and policy) effects of electing women to local government, this paper takes advantage of Tunisia's high level of representation of women in local councils (twenty-seven percent nationally in 2010) and data from the Tunisian Local Governance Performance Index (LGPI), an original survey conducted among 3,600 Tunisians in 2015 by the Governance and Local Development Center (GLD). ${ }^{10}$ The LGPI offers a sufficiently large number of respondents to permit analysis of subsamples of citizens who have contacted local officials and to compare proportions across municipalities.

\footnotetext{
${ }^{8}$ Lori Beaman et al., "Powerful Women: Does Exposure Reduce Bias?” The Quarterly Journal of Economics 124, no. 4 (2009): 1497-1540, https://doi.org/10.1162/qjec.2009.124.4.1497. ${ }^{9}$ Clayton, "Electoral Gender Quotas and Attitudes toward Traditional Leaders: A Policy Experiment in Lesotho." Other studies at the national level also show limited or no symbolic impacts of electing women. See for example, Pär Zetterberg, "Do Gender Quotas Foster Women's Political Engagement?: Lessons from Latin America," Political Research Quarterly 62, no. 4 (2009): 715-730, https://doi.org/10.1177/1065912908322411. Tiffany D. Barnes and Stephanie M. Burchard, "Engendering” Politics: The Impact of Descriptive Representation on Women's Political Engagement in Sub-Saharan Africa," Comparative Political Studies 46, no. 7 (2013), https://journals-sagepub-com.proxy.lib.pdx.edu/doi/abs/10.1177/0010414012463884. ${ }^{10}$ The LGPI was developed by Pierre Landry, Ellen Lust, Lindsay Benstead, and Dhafer Malouche.
} 
Two outcomes are of interest: Service and allocation responsiveness. ${ }^{11}$ Service responsiveness refers to assisting constituents with individualized services, such as help with licenses, government documents, or jobs. Allocation responsiveness refers to attracting district projects or resolving community needs. Policy responsiveness refers to lawmaking. Service, allocation, and policy responsiveness — that is, "advancing women's interests through ... policy making. ${ }^{12}$ - make up substantive representation. In clientelistic and transitional contexts, where councils and parliaments have limited if any lawmaking prerogatives and informality is critical in local politics, service and allocation responsiveness are essential functions of elected and appointed bodies.

The findings show that electing female local councilors improves service and allocation responsiveness to women, in the form of increased interactions between women and local councilors, which fosters their ability to request help with personal or community problems or to

${ }^{11}$ Pitkin and Eulau and Karps conceptualized four dimensions of responsiveness (i.e., representation): Service, policy, allocation, and symbolic responsiveness. Hanna Fenichel Pitkin, The Concept of Representation. (Berkeley: University of California Press, 1967). Heinz Eulau and Paul D. Karps, "The Puzzle of Representation: Specifying Components of Responsiveness," Legislative Studies Quarterly 2, no. 3 (1977): 233-254, https://doi.org/10.2307/439340.

${ }^{12}$ Most research on substantive representation has been conducted in developed democracies and thus construed as policy responsiveness. See, e.g., Susan Franceschet, Mona Lena Krook, and Jennifer M. Piscopo, The Impact of Gender Quotas (New York: Oxford University Press, 2012). 
express an opinion. ${ }^{13}$ The LGPI shows that male citizens are thirteen percentage points more likely to know a councilor than are women and 6 percentage points more likely to contact a councilor. Yet, electing women increases women's access to local councilors, due to homosociality—that is, the tendency to have denser networks with others of the same gender. ${ }^{14}$ This is especially true of request for community concerns, two-thirds of which are often made through male-male or female-female networks. When asking for help with community issues, male and female citizens are twice as likely to contact a councilor of the same gender. Electing and appointing women supports women's service and allocation representation while having a limited impact on men's representation because female councilors have more heterosocial networks that include male citizens.

The findings underscore the need for gender quotas to improve women's access to local councilors and for policymakers to consider gender equity when implementing decentralization laws. The findings also suggest that while electing women helps level the gender gap in access to councilors in clientelistic settings, doing so does not automatically eliminate underlying power hierarchies. Most requests for major infrastructure and public works projects occur in male-male

\footnotetext{
${ }^{13}$ It is impossible to gauge how successful these interactions are, but the results show that female citizens are more able to meet female legislators than male legislators about community issues. ${ }^{14}$ Elin Bjarnegård, Gender, Informal Institutions and Political Recruitment: Explaining Male Dominance in Parliamentary Representation, Gender and Politics (Houndmills, Basingstoke,
} Hampshire: Palgrave Macmillan, 2013). 
dyads. This may be due to network homosociality, men's greater economic power and clout, and male professional competencies, which are often related to roads, water, and construction.

Tunisia is a hard case to find an impact of electing women on responsiveness to female citizens, due to its history of state-sponsored feminism and strong role of women in politics. Thus, electing women is likely to an even greater impact on women's service and allocation responsiveness in other societies in Africa and the Middle East (MENA).

\section{The Importance of Personal Networks and Clout in Tunisia's Local Politics}

During the Ben Ali era, mayors and municipal councils were elected, but were fiscally and administratively dependent on the central government and appointed governors through a system of tutelle (guidance). ${ }^{15}$ Under a law passed in the 1980s designed to consolidate power under the central government, local councils had limited revenue and policymaking prerogatives, making them largely dependent on Tunisia's central government. ${ }^{16}$ Decentralization was a "fiction." ${ }^{17}$ According to Clark, Dalmasso, and Lust, "a variety of forms of tutelle and oversight

\footnotetext{
${ }^{15}$ Janine Clark, Emanuela Dalmasso, and Ellen Lust, "Not the Only Game in Town: Local-Level Representation in Transitions," Working Paper 15, 2017, http://gld.gu.se/media/1325/lustdalmasso-clark-final.pdf.

${ }^{16}$ The central government set the parameters of the taxation system. Municipalities collected tax on land, industrial establishments, and hotels. Clark, Dalmasso, and Lust.

${ }^{17}$ Néji Baccouche, as cited in Sarah Yerkes and Muasher Marwan, "Decentralization in Tunisia: Empowering Towns, Engaging People," Carnegie Endowment for International Peace, May 17,
} 
reduced the municipality's role during the Ben Ali period largely to the management of buildings and services, primarily trash collection." ${ }^{18}$ Municipalities managed urban planning, but had little influence over health, education, and other vital services. ${ }^{19}$

Moreover, the RCD controlled political life through its national headquarters and local branches. The system of tutelle fostered municipal councils in which personal status, clout, and connections within the party, regional and central government and professional associations shaped what councilors could do. Councilors' role was largely to provide personal services such as government documents and, when possible, to influence public spending on infrastructure and public works, including electricity, water, or roads.

Despite Tunisia's political transition in 2011, a new decentralization law has not been passed and political clientelism remains prominent in local politics. ${ }^{20}$ Clientelism differs from

2018, https://carnegieendowment.org/2018/05/17/decentralization-in-tunisia-empowering-townsengaging-people-pub-76376.

${ }^{18}$ Interview with Mokhtar Hammami, the general director of the General Direction of Public Local Collectivities (GDPLC), conducted by Clark, Dalmasso, and Lust, "Not the Only Game in Town: Local-Level Representation in Transitions", 10.

${ }^{19}$ Yerkes and Marwan, "Decentralization in Tunisia."

${ }^{20}$ Clientelism is an "informal relationship between two actors of asymmetrical socioeconomic power where the patron ... controls ... resources ... clients pursue but often cannot receive otherwise" Luigi Manzetti and Carole J. Wilson, "Why Do Corrupt Governments Maintain 
service responsiveness (i.e., casework) or allocation responsiveness (i.e., district projects), two dimensions of democratic representation. ${ }^{21}$ Clientelism is accessed and distributed through informal networks, is not transparent, and does not foster government accountability through bureaucratic oversight or legislation. Yet, while local councils have a limited formal role in policymaking or budgetary control, they are important intermediaries between the central government and the population and are thus well placed to influence decisions about local governance. $^{22}$

Clientelistic responsiveness constitutes a form of women's representation when women and women's groups are served in equal measure to men. ${ }^{23}$ As marginalized members of society—and particularly the most patriarchal societies—women often need help accessing government services and resolving bureaucratic bottlenecks. Yet, they are less likely to have linkages with political elites than male citizens. Women's access to local councilors is critical for

Public Support?," Comparative Political Studies 40, no. 8 (2007): 949-970, https://doi.org/10.1177/0010414005285759..

${ }^{21}$ Eulau and Karps, "The Puzzle of Representation."

${ }^{22}$ Benstead, “Why Quotas Are Needed to Improve Women's Access to Services in Clientelistic Regimes."

${ }^{23}$ Lisa Blaydes and Safinaz El Tarouty, "Women's Electoral Participation in Egypt: The Implications of Gender for Voter Recruitment and Mobilization,” The Middle East Journal 63, no. 3 (2009): 364-380, https://doi.org/10.3751/63.3.11. 
addressing personal requests and is a pathway for allocation and policy representation. ${ }^{24}$ This is particularly true when women ask for help with community needs, such as education, water, or roads. ${ }^{25}$

\section{Explaining Gender Gaps in Contacting Local Councilors}

Despite the importance of local councils' responsiveness to personal and community needs to margined groups, little is known about how women's presence affects service and allocation responsiveness to women at the local level. Clientelistic settings like Tunisia, where councils are weak and dependent on relationships with the regional and central government, have been shown to limit women's access to elected and appointed officials. ${ }^{26}$ This is due to the numerical dominance of men and the tendency toward homosociality in service networks (i.e., friendships, collaborations, and other non-romantic relationships with others of the same gender). ${ }^{27}$ Bjarnegård argues, men have advantages accumulating homosocial capital — that is, predictable relationships with individuals who are similar and have resources needed to win elections - due to their numerical dominance in politics. Women's underrepresentation in

${ }^{24}$ Kudva, "Engineering Elections."

${ }^{25}$ Pande, "Can Informed Voters Enforce Better Governance?”

${ }^{26}$ Benstead, “Why Quotas Are Needed to Improve Women's Access to Services in Clientelistic Regimes."

${ }^{27}$ Jean Lipman-Blumen, "Toward a Homosocial Theory of Sex Roles: An Explanation of the Sex Segregation of Social Institutions," Signs 1, no. 3 (1976): 15-31, https://doi.org/10.1086/493272. 
government leads to lower rates of clientelistic service provision to women ${ }^{28}$ that can also limit substantive representation of women's issues.

Homosocial capital is composed of instrumental and expressive resources. ${ }^{29}$ Expressive resources are dispositional similarities which facilitate close, predictable relationships and access to instrumental resources needed to succeed in campaigns. ${ }^{30}$ Men and women often prefer friendship and collaboration, including political networking and cooperation, with others of the same gender, due to greater ease relating (e.g., similar behavior and interests, fewer conflicts and sexual harassment concerns, higher trust). Yet, male dominance in political life is reproduced because instrumental and expressive resources are seldom in opposition for men. Males have more instrumental resources and can rely on homosocial linkages with other men, with whom they connect easily. In contrast, women must foster heterosocial networks to obtain resources, while enjoying less expressive resources, such as trust and familiarity, in networks with men. ${ }^{31}$

${ }^{28}$ Benstead, “Why Quotas Are Needed to Improve Women's Access to Services in Clientelistic Regimes."

${ }^{29}$ Bjarnegård, Gender, Informal Institutions and Political Recruitment. ${ }^{30}$ Bjarnegård.

${ }^{31}$ Bjarnegård; Herminia Ibarra, "Homophily and Differential Returns: Sex Differences in Network Structure and Access in an Advertising Firm," Administrative Science Quarterly 37, no. 3 (1992): 422-447, https://doi.org/10.2307/2393451. 
Exclusion of women from service provision occurs through mutually-reinforcing structural and dispositional factors operating on the supply and demand-side of exchanges. ${ }^{32}$ On the instrumental, supply-side, patriarchal structures limit female deputies' instrumental resources needed to provide services. Because women have less dense clientelitsic networks with the regional and national government and their parties — and because they are less often in professions relevant to local governance in Tunisia (e.g., public works) — they are also less able to impact substantive outcomes, especially public goods that require more clout than personal services to influence. Fewer citizens may approach female members for help, particularly if they perceive that a male councilor would be better placed to address their request. Women's diminished ability to use elected and appointed officials as a source of wasta (intermediary) can also have symbolic effects. ${ }^{33}$ If female leaders enjoy fewer patronage networks, ${ }^{34}$ they will be

${ }^{32}$ Benstead, “Why Quotas Are Needed to Improve Women's Access to Services in Clientelistic Regimes."

${ }^{33}$ In the Arab world, clientelism is a form of wasta (using connections, an intermediary) through which loyalty to family, tribe, religion, and sect is used to achieve mutually beneficial exchanges of interests. Basem Sakijha and Sa'eda Kilani, Wasta: The Declared Secret. Amman: Arab (Archives Institute, 2002).

${ }^{34}$ Aili Mari Tripp, “The Politics of Autonomy and Cooptation in Africa: The Case of the Ugandan Women's Movement," The Journal of Modern African Studies 39, no. 1 (2001): 10128. 
less likely to be seen as good sources of wasta (intermediary) and are less able to run in and win elections. $^{35}$

Patriarchal norms limit female deputies' interactions with male elites, due to social norms (i.e., the expressive, supply side) and female citizens' interaction and networks with male deputies (i.e., the expressive, demand side). Patriarchal structures exclude women from public space (e.g., employment, politics), giving them fewer resources and influence (i.e., the instrumental, demand side). Women are less likely to be politically engaged ${ }^{36}$ or lead civil society groups, Sufi brotherhoods, and tribes, whose support is critical for winning elections. The Transitional Governance Project finds voting in first post-uprisings parliamentary elections is seventy-seven percent for Egyptian men, fifty-eight percent for women; seventy-five percent for Tunisian men, sixty-five percent for women; and eighty-four percent for Libyan men, fifty-nine percent for women. ${ }^{37}$ Females are perceived as less able to deliver votes and thus as less strategically important to target with services.

${ }^{35}$ Benstead, "Why Quotas Are Needed to Improve Women's Access to Services in Clientelistic Regimes."

${ }^{36}$ Ethan M. Bernick and Sabri Ciftci, "Utilitarian and Modern: Clientelism, Citizen Empowerment, and Civic Engagement in the Arab World," Democratization 22, no. 7 (2014): 122, https://doi.org/10.1080/13510347.2014.928696.

${ }^{37}$ Lindsay J. Benstead and Ellen Lust, "Women's Political Participation in North Africa: Lessons from Recent Research,” Middle East Institute. MAP Essay Series, 2015, http:// www.mei.edu/content/map/civil-society-and-political-transitions-mena-region-and-asia. 
A few surveys including the Constituent Survey ${ }^{38}$ in Morocco and Algeria and the Tunisian Post-Election Survey ${ }^{39}$ conducted by the author, offer evidence that women are less able to access help from local councilors. As shown by the 2007 Constituent Survey, in Morocco, twenty-six percent of men and sixteen percent of women had contacted a member of a local council in the previous five years - a gap of ten percent. In Algeria, twenty-nine percent of men and twenty percent of women asked for help from a local councilor - a gap of nine percent. Fewer constituents overall had contacted a regional official than a local official and the gender gap was smaller-zero percent in Morocco and five percent in Algeria (see Figure 1). The data

${ }^{38}$ Lindsay J. Benstead and Ellen Lust, "Constituent Survey," 2007-2008. The Constituent Surveys were nationally representative survey conducted in Morocco and Algeria in 2007-2008 among 800 in each country.

${ }^{39}$ In the 2012 Tunisian Post Election Survey (TPES), a different survey conducted three years before the LGPI, seventeen percent of men and sixteen percent of women reported that they had contacted a member of the local council since the revolution. This is a non-significant difference. Lindsay J. Benstead and Ellen Lust, "Tunisian Post Election Survey (TPES),”2012, http://transitionalgovernanceproject.org/. The TPES was conducted among 1,220 constituents in 2012 by Lindsay Benstead and Ellen Lust and is part of the Transitional Governance Project. 
show that gender gaps in access to services are at least as large as the local and regional levels of government than for national parliamentarians..$^{40}$

Figure 1. Percentage contacting local and regional councilors in the last five years in Morocco and Algeria

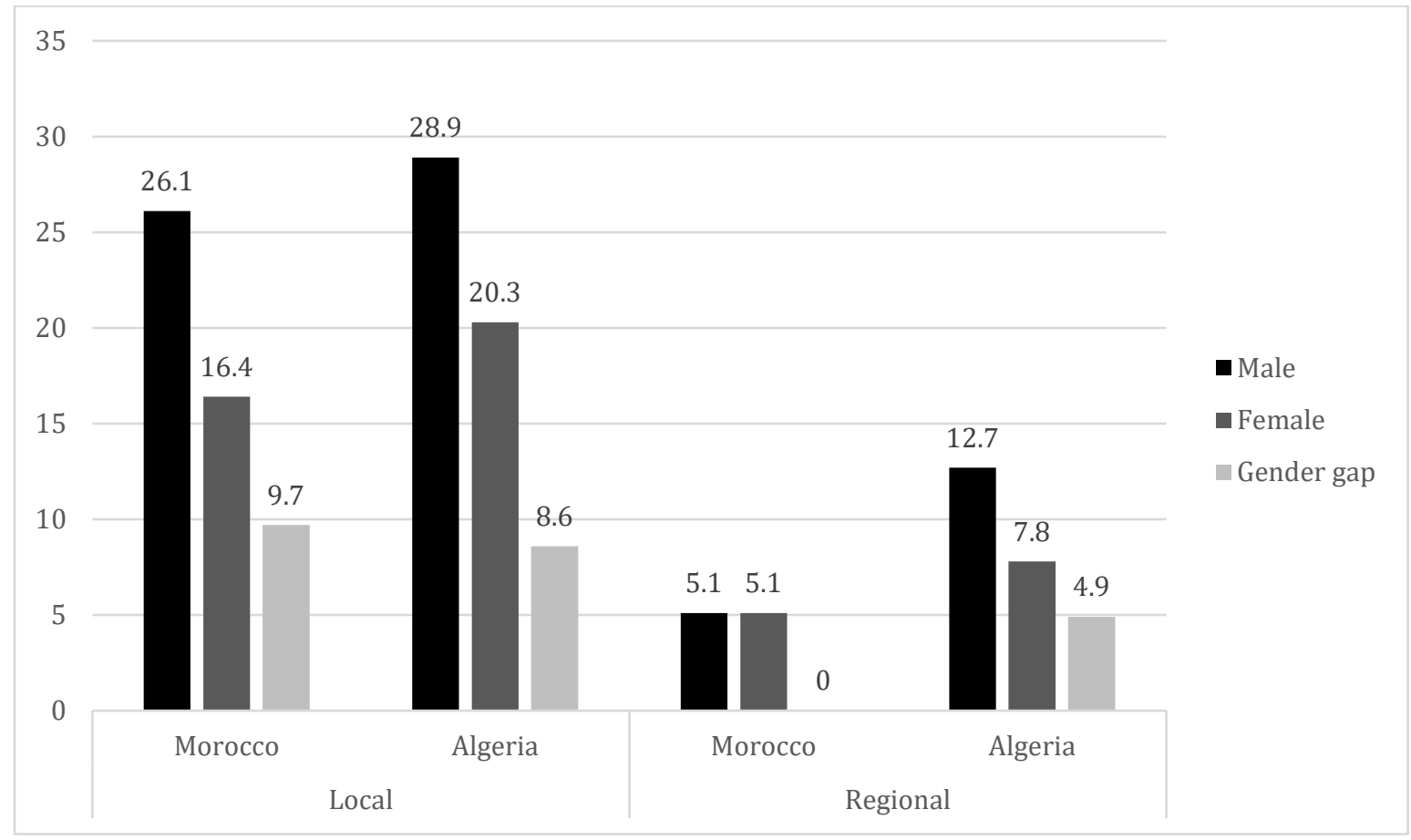

Source: Constituent Survey. Question wording: Local Councils (APCs) Have you or any member of your household tried either successfully or unsuccessfully to contact an elected official of your local council to seek help with a personal problem, to seek help with a social or economic problem your community is facing, or to express an opinion? $\mathrm{No}(=1)$, Yes $(=1)$, Yes we tried, but could not contact(=1). Regional Councils $\left(A P W_{S}\right)$ As above ("APW").

${ }^{40}$ Mounah Abdel-Samad and Lindsay J. Benstead, "Why Do Islamist Parties Reduce the Gender Gap in Service Provision to Women?” (Kansas State University, 2016). For additional analysis, see Appendix 1, Table A1. 
Existing literature shows that women's access to national parliamentarians increases the more females hold office. ${ }^{41}$ Afrobarometer data suggest women are less likely to contact parliamentarians: 11.7 percent of Moroccan men, compared to 3.5 percent of women $(p<0.000)$ and 2.2 percent of Algerian men, compared to 1.7 percent of Algerian women $(p<0.533)$ had contacted a parliamentarian in the previous year. ${ }^{42}$ Examining Morocco and Algeria, Benstead found that, on average, 20-29 percent of requests in both countries come from women, but female parliamentarians are more likely to serve women than are male deputies. Moreover, according to the Arab Barometer, ${ }^{43} 56.6$ percent of men and 43.4 percent of women in six Arab countries used wasta (intermediary) of any type during the last five years.

Yet, electing women to local councils can reduce these gaps by increasing women citizens' homosocial capital and thus their demand for services and community goods. Accordingly, I expect that female citizens will be less likely to be able to contact local councils than men, due to the numerical dominance of men in local government and male citizens' advantages accumulating homosocial capital, which allows them to interact with and contact councilors more easily (H1). The gender gap in contacts will decrease as more females hold local office because females will be more able to seek services from female members than from male members, due to homosociality in networks. This will occur because females will be more likely

\footnotetext{
${ }^{41}$ Abdel-Samad and Benstead; Benstead, "Why Quotas Are Needed to Improve Women's Access to Services in Clientelistic Regimes."

42 “Afrobarometer," accessed November 28, 2018, http://www.afrobarometer.org/. 43 “Arab Barometer," Wave 1, 2008 2006, http://www.arabbarometer.org/.
} 
to contact female than male councilors for help with personal and community requests $(\mathrm{H} 2)$.

However, since female political leaders are more likely to have heterosocial networks—-due to their need to mobilize support from men as well as women-electing females will have a limited impact on males' access to councilors. ${ }^{44}$ Males, I expect, will be as likely to contact female councilors as male councilors for help with personal and community requests (H3).

\section{Hypotheses:}

H1: Women will be less likely than men to know and contact local councilors.

H2: Women will be more likely to contact female than male councilors for help with personal and community requests.

H3: Men will be as likely to contact female councilors as male councilors for help with personal and community requests.

\section{Data and Methodology}

The data used to test these hypotheses are from the Local Governance Performance Index (LGPI), a survey of nearly 3,600 Tunisians conducted in February 2015 by the Program on Governance and Local Development (GLD). The survey includes approximately 200 interviews in each of 18 municipalities (Table 1). The LGPI's large sample size of 3,600 respondents allows for fine-grained analysis of a relatively uncommon experience of contacting local officials. About 489 respondents (fourteen percent of the sample) had asked a local councilor for help in the previous year.

\footnotetext{
${ }^{44}$ Bjarnegård, Gender, Informal Institutions and Political Recruitment; Ibarra, "Homophily and Differential Returns."
} 


\section{Municipalities}

The municipalities represent a wide range of urban and rural districts located in the North and Center of the country and have varying economic profiles. The rate of water hookup in homes is lowest in Siliana-Nord/Ville (70.1 percent) and highest in Sfax-Ville (98.0 percent). Sfax is a regional hub, while Siliana is located $127 \mathrm{~km}$ from the closest major city (Table 1).

Citizens in the selected municipalities have varying access to local councilors. The proportion who contacted a councilor for help with a personal problem, community issue, or to express an opinion varies from seven percent in Souassi (governorate of Mahdia) to thirty percent in Moknine (governorate of Monastir). The gender of the councilors who were contacted also varies. In some districts (Jebel-Jelloud, Bizerte-Nord, Bizerte-Sud, Ksour-Essaf, Souassi, and Bou-Arada) none of the citizens who contacted a local councilor indicated that the councilor was female, while the proportion of contacts with female councilors reached twenty-nine percent in Cite-El- Khadra, a municipality in Tunis. The proportion of women who have asked for help from any councilor ranges from one percent in Jebel-Jelloud (governorate of Tunis) to twentyseven percent in Moknine (governorate of Monastir). 
Table 1. Characteristics of municipalities

\begin{tabular}{|c|c|c|c|c|c|c|c|c|}
\hline Governorate & Municipality & Region & $\%$ rural $^{2}$ & $\begin{array}{l}\text { Rate of } \\
\text { potable } \\
\text { water } \\
\text { hookup }\end{array}$ & $\begin{array}{l}\text { Distance to } \\
\text { regional hub } \\
\text { (Tunis, Sousse, } \\
\text { or Sfax) }\end{array}$ & $\begin{array}{l}\% \text { Who } \\
\text { contacted a local } \\
\text { councilor of } \\
\text { either gender }{ }^{2}\end{array}$ & $\begin{array}{l}\% \text { Who } \\
\text { contacted } \\
\text { a female } \\
\text { councilor }^{2}\end{array}$ & $\begin{array}{l}\% \text { Women } \\
\text { who } \\
\text { contacted a } \\
\text { councilor }\end{array}$ \\
\hline Sfax & Sfax-Ville & Center East & $0.0 \%$ & 98.00 & 1.00 & $25.4 \%$ & $18.0 \%$ & $18.9 \%$ \\
\hline Sfax & Sfax-Sud & Center East & $0.0 \%$ & 88.70 & 2.00 & $13.3 \%$ & $14.3 \%$ & $13.6 \%$ \\
\hline Sfax & Sakiet- Eddaier & Center East & $0.9 \%$ & 92.90 & 5.00 & $14.3 \%$ & $10.7 \%$ & $13.9 \%$ \\
\hline Tunis & Jebel-Jelloud & North East & $0.0 \%$ & 97.60 & 5.00 & $2.0 \%$ & $0.0 \%$ & $0.9 \%$ \\
\hline Tunis & Cite-El- Khadra & North East & $0.0 \%$ & 97.70 & 6.00 & $9.4 \%$ & $29.4 \%$ & $5.7 \%$ \\
\hline Tunis & La-Marsa & North East & $0.5 \%$ & 96.10 & 19.00 & $13.9 \%$ & $4.6 \%$ & $15.2 \%$ \\
\hline Monastir & Monastir & Center East & $2.1 \%$ & 94.90 & 22.00 & $25.4 \%$ & $27.6 \%$ & $18.0 \%$ \\
\hline Monastir & Moknine & Center East & $17.3 \%$ & 92.10 & 36.00 & $29.9 \%$ & $12.5 \%$ & $26.7 \%$ \\
\hline Monastir & Teboulba & Center East & $100.0 \%$ & 93.10 & 42.00 & $11.3 \%$ & $16.7 \%$ & $9.3 \%$ \\
\hline Bizerte & Menzel-Jemil & North East & $37.1 \%$ & 94.30 & 59.00 & $8.8 \%$ & $11.8 \%$ & $6.7 \%$ \\
\hline Mahdia & Mahdia & Center East & $10.2 \%$ & 93.70 & 60.00 & $14.2 \%$ & $4.4 \%$ & $14.0 \%$ \\
\hline Bizerte & Bizerte-Nord* & North East & $12.9 \%$ & 95.40 & 65.00 & $9.1 \%$ & $0.0 \%$ & $4.8 \%$ \\
\hline
\end{tabular}




\begin{tabular}{|l|l|l|l|l|l|l|l|l|}
\hline Bizerte & Bizerte-Sud* & North East & $20.4 \%$ & 74.30 & 65.00 & $8.4 \%$ & $0.0 \%$ & $5.9 \%$ \\
\hline Mahdia & Ksour-Essaf & Center East & $97.9 \%$ & 84.10 & 70.00 & $8.5 \%$ & $0.0 \%$ & $1.1 \%$ \\
\hline Mahdia & Souassi & Center East & $50.7 \%$ & 58.60 & 81.00 & $7.5 \%$ & $0.0 \%$ & $4.4 \%$ \\
\hline Siliana & Bou-Arada & North West & $54.5 \%$ & 69.50 & 93.00 & $16.9 \%$ & $0.0 \%$ & $8.1 \%$ \\
\hline Siliana & Gaafour & North West & $97.1 \%$ & 72.50 & 110.00 & $16.6 \%$ & $6.3 \%$ & $17.9 \%$ \\
\hline Siliana & Siliana-Ville & North West & $16.7 \%$ & $70.10^{4}$ & $127.00^{4}$ & $11.3 \%$ & $15.8 \%$ & $2.9 \%$ \\
\hline
\end{tabular}

Source: ${ }^{1}$ National Institute of Statistics. Data file provided directly to author. ${ }^{2}$ LGPI. ${ }^{3}$ Yerkes and Muasher. ${ }^{4}$ Siliana-Nord. 


\section{Representation in Local Councils}

Local elections were held in May 2010 shortly before the December 2018-January 2019 revolution. Since local elections had not yet taken place, some mayors and councilors who were elected in 2010 under Ben Ali were still in power when the LGPI was administered in February 2015. However, immediately following the departure of Ben Ali, the government took steps through the Ministry of Interior (MOI) to replace local councils with appointed Special Delegations made up of protesters and activists until new local elections could take place. According to Mokhtar Hammami, general director of the General Direction of Public Local Collectivities (GDPLC), the Ministry of Interior (MOI) directive issued on January 14, 2011 calling on governors to propose lists of activists and protesters who had been involved in local affairs but not in formal politics under Ben Ali. ${ }^{45}$ The Islamist Ennahda party won a plurality of seats (thirty-seven percent) in the 2011 Constituent Assembly elections and governed in a Troika with two leftist parties, CPR and Ettakatol.

The Troika's continued efforts to replace the local councils were only partially successful. While Ennahda wanted to make the local governments more representative of the parties in power and the Troika after the revolution, they succeeded in creating Special Delegations to replace local councils only where existing councils had less support of leftist parties and weaker links with the national union, the UGTT. Yet, changes in the SD between 2011 and 2015 were made in sixteen of the eighteen municipalities included in the LGPI survey.

\footnotetext{
${ }^{45}$ Clark, Dalmasso, and Lust, "Not the Only Game in Town: Local-Level Representation in Transitions."
} 
Some SDs were short lived and changed again between 2015 and 2018, after the survey was conducted. ${ }^{46}$

The MOI directive called on governors to "list the human resources available within the administration, and the apolitical persons, those who have never been involved in politics before - persons that have been involved in public affairs before but not in politics, and also young people and women" in order to dissolve municipal councils and replace them all with Special Delegations." ${ }^{47}$ Including women would have been natural, since women are wellrepresented in Tunisia's civil society movements and political life more broadly and thus provide a pool for recruitment. Moreover, the Islamist Ennahda party, which held a plurality of seats in the Constituent Assembly, promoted women in their ranks. Women made up 41 percent of Ennahda's deputies and three-quarters of all the women elected to the Constituent Assembly. Ennahda also utilized large numbers of women in party offices to mobilize voters. The party had 240 Women's Committees to campaign in all of Tunisia's 24 wilayat, with 320 women acting as heads of these committees. ${ }^{48}$

${ }^{46}$ Some governors and secretary generals also changed.

${ }^{47}$ Interview with Mokhtar Hammami, the general director of the General Direction of Public Local Collectivities (GDPLC), conducted by Clark, Dalmasso, and Lust, "Not the Only Game in Town: Local-Level Representation in Transitions." 12.

${ }^{48}$ Andrea Khalil, “Tunisia's Women: Partners in Revolution,” The Journal of North African

Studies 19, no. 2 (March 15, 2014): 186-99, https://doi.org/10.1080/13629387.2013.870424. 
Thus, in asking about citizens interactions with local councilors since the 2010 elections, this paper examines a mix of local councils, both those elected in 2010 as well as, in some cases, those appointed by the Troika after the revolution. In the districts included in the LGPI, the proportion of women in these SDs ranged from zero percent in Bou-Arada (governorate of Mahdia), Teboulba (governorate of Monastir), and Essouassi (governorate of Siliana) to fortytwo percent in La Marsa (governorate of Tunis). ${ }^{49}$ In those that did not have SDs, the proportion of women was likely around 27 percent, due to the RCD's voluntary party quota of thirty percent in 2010. Citizens reported their interactions with local councilors, who could have been from their municipality or another municipality.

\section{Service and Community Goods Requests}

Figure 2 shows the proportion of times that citizens contacted a local councilor about an issue in the year preceding the survey. Since respondents could ask for more than one request in a single meeting, the proportion of requests exceeds one hundred percent. In Tunisia, the most common requests were for roads and government licenses and documents. Thirty-four percent of meetings and other contacts were to ask for help with roads or government documents, respectively.

\footnotetext{
${ }^{49}$ Author's records based on decrees contained in "Official Gazette of the Republic of Tunisia," accessed December 2, 2018, http://www.legislation.tn/en/recherche/legislatifsreglementaires/numero_jort/last/codem/0014/sort/date.
} 
Figure 2. Reasons for contacting a local councilor in Tunisia (Percentage of total requests)

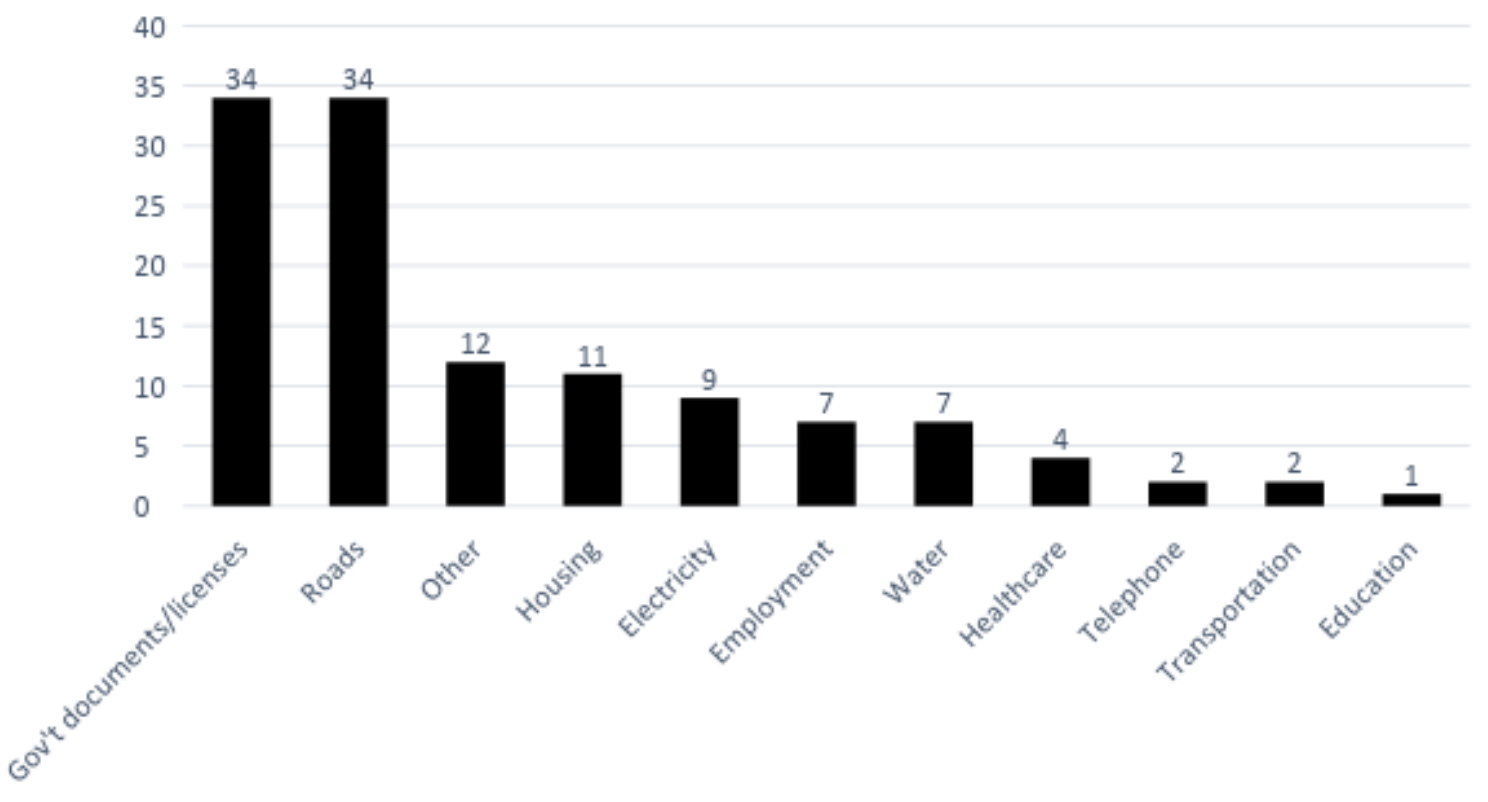

Percent of requests

Source: LGPI. Four bars for each service type sum to more than one-hundred percent because respondents can state more than one type of service requested. Question wording: "(The last time you contacted a member of the local council) what type of issue did you address?"

Other, unspecified types of requests that were not captured by the response categories accounted for twelve percent, housing made up eleven percent of requests, and electricity accounted for nine percent. Less common requests included employment (seven percent), water (seven percent), healthcare (four percent), transportation and telephone (two percent, respectively), and education (one percent). This suggests that despite having limited tax resources or administrative autonomy, local councilors are able to influence allocation of public works, such as roads and electricity. It also suggests an important role of clientelistic 
relationships in accessing and providing government services, with potentially deleterious effects on equal access for women and men.

\section{Request Type and Volume by Councilor Gender}

Citizens brought different types of requests to male and female councilors. As shown in Figure 3, requests for large public works projects were made overwhelmingly to male councilors. One hundred percent of requests for help with water and transportation were made to male councilors; ninety-four percent of requests for healthcare and ninety-two percent of requests for roads $(\mathrm{p}<.01)$ were made to men. Similar proportions - ninety-one percent of requests for electricity and housing $(\mathrm{p}<.05)$ - were made to men. Ninety percent of requests for help for employment.

This may because men are more likely to have professional competencies and networks in construction and industrial fields, greater political clout, and denser political networks needed to influence resources from the regional and central government in order to influence these major requests. 


\section{Figure 3. Requests by local councilor gender}

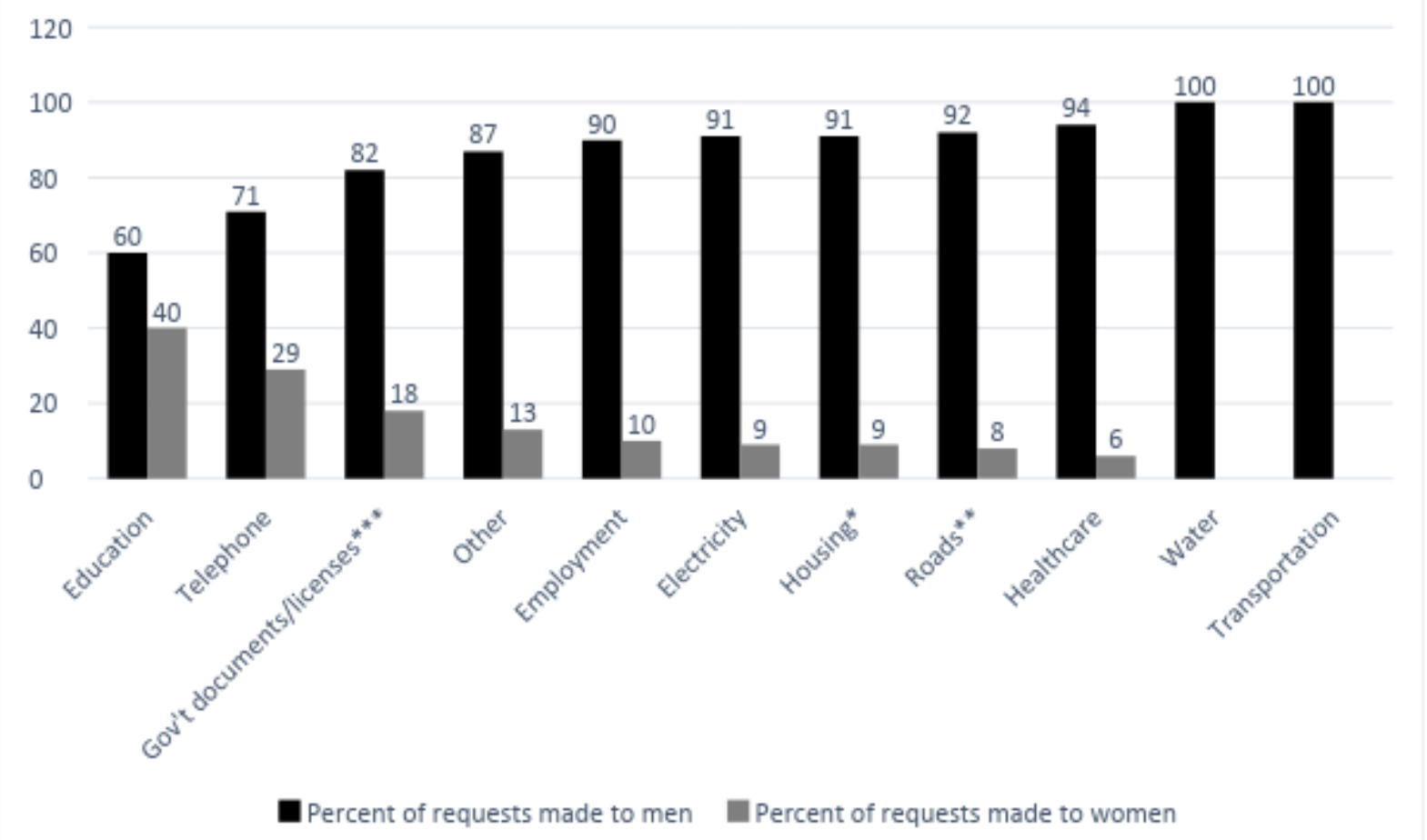

Source: LGPI. $* * * p<.001, * * \mathrm{p}<.01, \mathrm{p}<.05$. Question wording: (The last time you contacted an official) was the member you contacted male or female?

In contrast, female councilors are more often approached to provide help with education, telephone, government documents $(\mathrm{p}<.001)$, and “Other," unspecified requests. Although fewer than one percent of all requests are for education, forty percent are made to female councilors. In addition, twenty-nine percent of requests for telephone services (which make up only two percent of all requests made to councilors) are made to female councilors, while eighteen percent of requests for government documents and licenses are directed toward female councilors. Female councilors receive fewer requests overall, and when they are approached, it is rarely 
regarding public works. This suggests that female citizens face two types of disadvantages: they have fewer chances to meet councilors and when they do, they meet with women, who are relatively unlikely to address community issues such as public works.

\section{Request Type and Volume by Citizen Gender}

Male citizens have greater rates of contacts with local councilors; they ask for sixty percent of all requests (despite making up half the population) and are more likely than women to request every type of service mentioned in the survey. When it comes to personal service requests, fifty-two percent of "Other" requests are made by men, fifty-five percent of requests for healthcare are from men, and fifty-seven and fifty-eight percent of requests for electrical and water come from men, respectively (Figure 4).

The gender gap grows even greater for public works requests. Sixty percent of requests for roads come from men $(\mathrm{p}<.01)$; sixty-two percent of requests for telephone and government documents (p.>001) come from men. Sixty-three percent of employment requests come from men. Sixty-five percent of requests for housing come from men $(p<.05)$ and seventeen percent of requests for transportation come from men. Men and women may have different policy preferences and thus approach leaders of about issues, as Chattopadhyay and Duflo suggest regarding India. ${ }^{50}$ Or, due to male citizens' advantages accumulating homosocial capital, they may have greater access to councilors, which allows them to address different issues.

\footnotetext{
${ }^{50}$ Chattopadhyay and Duflo, "Women as Policy Makers."
} 
Figure 4. Requests by citizen gender

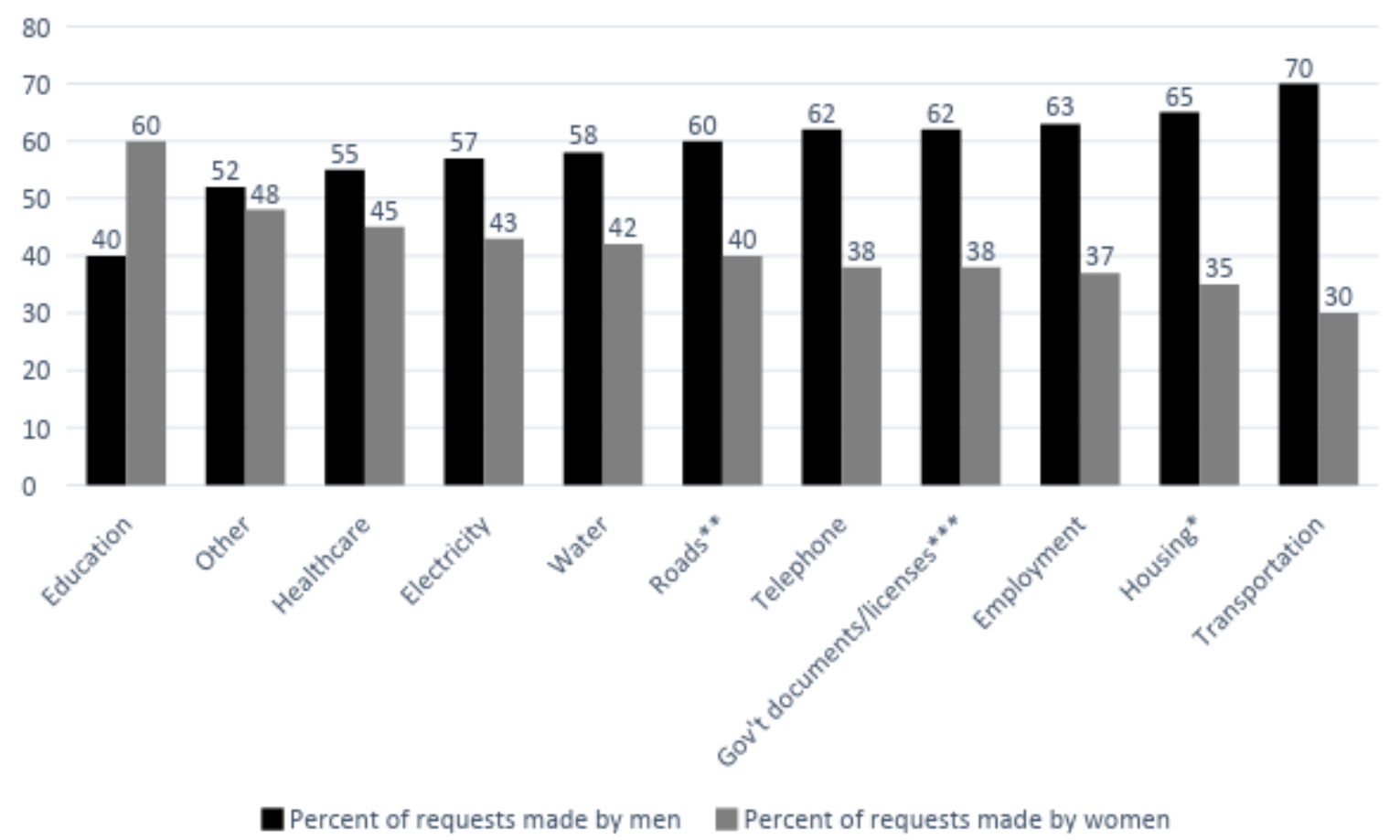

Source: LGPI. $* * * \mathrm{p}<.001, * * \mathrm{p}<.01, \mathrm{p}<.05$.

\section{Evaluating the Impact of Electing and Appointing Women}

To what extent does homosociality in citizen-local councilor networks explain the gender gap in service and allocation responsiveness? Does electing women decrease the gap? ${ }^{51}$

\section{Measurement}

${ }^{51}$ This item measures whether respondents made requests, not whether they actually received the services or resources. 
To measure the dependent variables, service and allocation responsiveness, I use an item measuring whether the respondent knows a member of his or her Majlis Baladiyya (Local council)/Niabba Khassousiya (Special Delegation), which is relevant for predicting who is likely to be able to access a councilor. To measure service responsiveness, I use an item measuring whether the respondent contacted a member of the Majlis Baladiyya (Local council)/Niabba Khassousiya (Special Delegation) during the last year, followed by the gender of the councilor. Questions about whether the interaction concerned a personal problem measures service responsiveness, while questions about whether the contact was about a community problem is used to tap allocation responsiveness. ${ }^{52}$ (See Appendix 2 for question wording).

To measure the independent and control variables for the multivariate analysis, I use female gender, age in years, and marital status, where never married is zero and married, engaged, widowed, separated, or divorced is one. Higher income is measured on a five point scale from low $(=1)$ to high $(=4)$. Education has four categories: no schooling $(=1)$, primary $(=2)$, secondary ( $=3)$, and college or above $(=4)$. Higher religiosity is measured on a scale of one (never prays, goes to mosque, or reads/listens to religious literature) and five (often does these things). Urban residence is measured according to whether the interview is located in an urban (mutadiya $=0$ ) or rural (immada $=1$ ) commune using the Census designation, and district fixed effects are included for the localities.

\section{Descriptive Statistics}

\footnotetext{
${ }^{52}$ Only a few citizens stated that they contacted a member to share an opinion; this is not include in the analysis.
} 
First, I examine bivariate relationships between the dependent variables and respondent gender. In support of H1, I find a thirteen percentage point gender gap in the extent to which citizens know a councilor from their municipality (Figure 5). Twenty-nine percent of men and sixteen percent of women know a councilor $(\mathrm{p}<.001)$. In addition, men are more likely than women by six percentage points to contact local councilors about any issue, whether personal or community related. Seventeen percent of men and eleven percent of women have contacted a member of a local council in the last year, a statistically significant difference $(\mathrm{p}<.000)$. When broken down by request type, nine percent of men and five percent of women contacted a councilor about a personal problem, while eight percent of men and five percent of women contacted a councilor about a community problem, both statistically significant differences $(\mathrm{p}<.001)$. Overall, women who consulted a councilor reported being more satisfied than did men $(p<.05) .{ }^{53}$ Women may be more likely to have their problems resolved, or they may be more prone to agreeableness in responding to attitudinal questions. ${ }^{54}$

${ }^{53}$ This difference is not statistically significant in the multivariate model.

${ }^{54}$ This is consistent with other survey data collected in Tunisia three years earlier in 2012 by Ellen Lust, Lindsay Benstead, and Dhafer Malouche. In the nationally-representative Tunisian Post Election Survey (TPES), which surveyed 1,200 respondents, males were also more likely than females to ask councilors for help with community problems or to express an opinion. Thirty-four percent of males and sixteen percent of females did so - a gender gap of eighteen percentage points. Women tend to ask local councilors for individualized services such as employment and healthcare, while males are more able to share an opinion or ask for community 


\section{Figure 5. Gender gaps in interactions with local councilors}

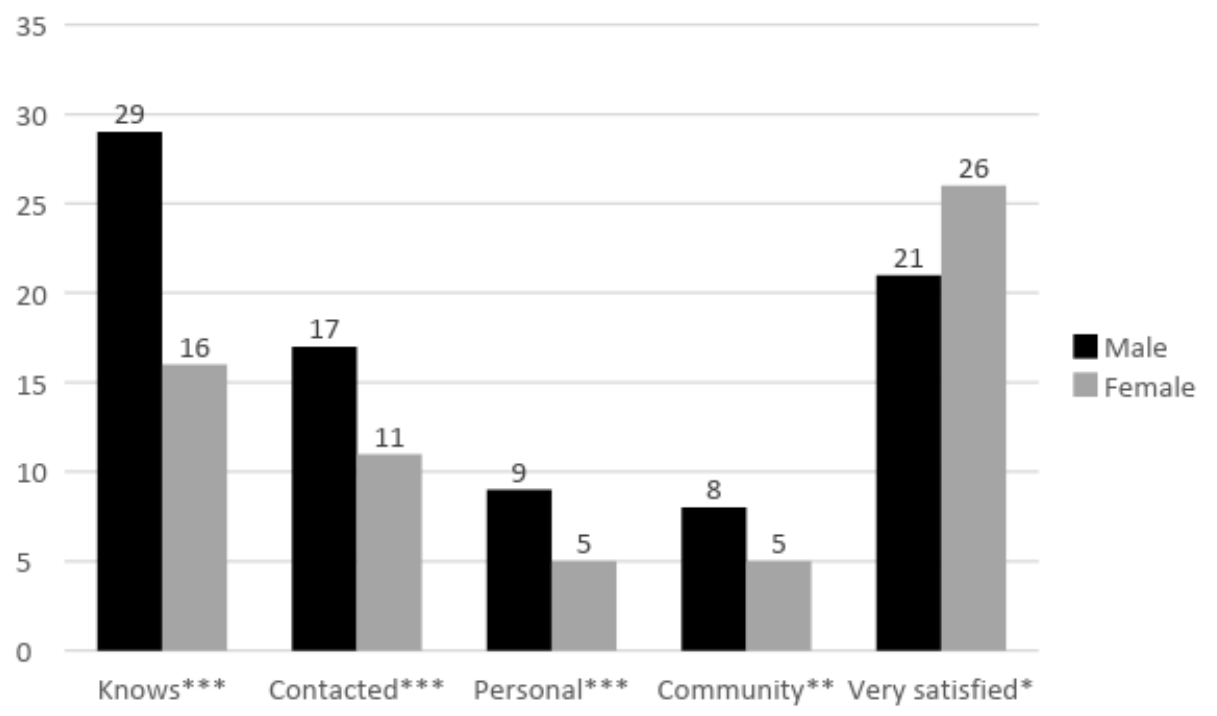

Figure 5 shows significant gender gaps in citizens interacting with local councilors. ${ }^{* * *} \mathrm{p}<.001$, ${ }^{* *} \mathrm{p}<.01, \mathrm{p}<.05$ Question Wording: Do you personally know any local council members in this municipality? In the last year, have you contacted a member of the Majlis Baladiyya (Local council)/Niabba Khassousiya (Special Delegation)? The last time you contacted a member of the local council, was it about a personal or community problem? (The last time you contacted an official), were you very satisfied, somewhat satisfied, somewhat dissatisfied, or very dissatisfied with the response?

Overall, the data suggest that males' advantages accumulating homosocial capital account for the gender gap in responsiveness. Men are more able to approach male councilors than are women, in support of H1. Males are more likely by a large margin to approach male

issues such as infrastructure and water. This raises questions about substantive representation of women's issues when women are more able to bring community requests to female councilors, but female councilors are less able than men to resolve problems, particularly those requiring substantial clout. 
councilors than female citizens in the sample as a whole. ${ }^{55}$ When it comes to personal services and community resources, about 63 percent of those who contact male councilors are male, compared to thirty-six percent who are female. Male councilors are approached more often to supply services and community resources than are female councilors. This suggests that because male citizens are more likely to know councilors than are female citizens, councilors are more responsiveness to the needs of men than women (Figure 6).

Yet, women are more likely to be able to contact female than male councilors, in support of H2. Fifty-five percent of those who contact female councilors are female, compared to fortyfive percent who are male. Women are especially likely to use networks with female councilors for community resource requests. Sixty-two percent of those who contact female councilors for help with club goods are female compared to thirty-seven percent who are male. Yet, this does not extend to asking for personal services. Males are slightly more likely to contact female councilors for personal services than are females, with male accounting for fifty-two percent of those who contact female councilors. This supports H3, which suggests that female councilors are more welcoming to female citizens than male councilors, and that to a significant extent they have heterosocial networks that include male citizens. ${ }^{56}$

${ }^{55}$ When examining interactions at the municipal level, men are significantly more likely to contact a local councilor in six of the eighteen municipalities $(\mathrm{p}<.05)$. The difference is not statistically significant in twelve municipalities.

${ }^{56}$ Ibarra, "Homophily and Differential Returns." 
Figure 6. Percentage requesting help with a personal or community problem by citizen and local councilor gender

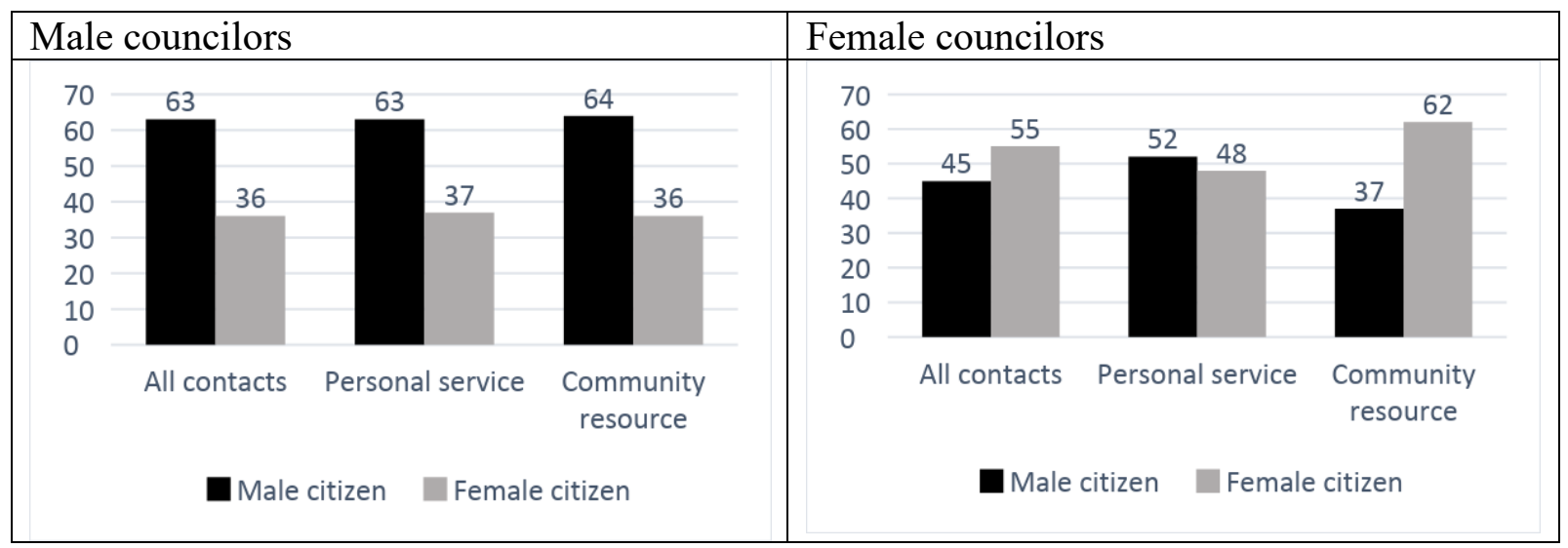

\section{Multivariate Statistics}

Logistic regression using fixed effects for municipalities shows that these gender differences in service and allocation responsiveness are robust when controlling for respondent age, marital status, income, education, religiosity, and rural or urban residence, in support of $\mathrm{H1}$ (Table $2 \& 3$ ). All else being equal, women are twelve percent less likely than men to know a councilor personally (Model 1). And, women are 6 percent less likely to have contacted a councilor during the last year (Model 2), three percent less likely to have asked for help with a personal problem (Model 3), and 2 percent less likely to have asked for help regarding a community problem $(\mathrm{p}<.01)$ (Model 4). 
Table 2. Determinants of knowing and contacting a councilor

\begin{tabular}{|c|c|c|c|c|}
\hline \multirow{3}{*}{ Model } & \multicolumn{2}{|c|}{ Model 1} & \multicolumn{2}{|c|}{ Model 2} \\
\hline & \multicolumn{2}{|c|}{ Knowing councilor } & \multicolumn{2}{|c|}{ Contacting councilor (all contacts) } \\
\hline & Logistic coefficients & $\begin{array}{l}\text { Marginal effects }{ }^{1} \\
\text { (Predicted } \\
\text { probabilities) }\end{array}$ & $\begin{array}{c}\text { Logistic } \\
\text { coefficients }\end{array}$ & $\begin{array}{c}\text { Marginal effects } \\
\text { (Predicted } \\
\text { probabilities) }\end{array}$ \\
\hline Individual-level & & & & \\
\hline Female & $-.78(.09)^{* * *}$ & $-.12(.01)^{* * *}$ & $-.56(.11)^{* * *}$ & $-.06(.01)^{* * *}$ \\
\hline Higher age & $.01(.00)^{*}$ & $.00(.00)^{*}$ & $.01(.00)^{*}$ & $.00(.00)^{*}$ \\
\hline Married & $.55(.13)^{* * *}$ & $.08(.02)^{* * *}$ & $.50(.15)^{* * *}$ & $.05(.01)^{* * *}$ \\
\hline Higher income & $-.18(.06)^{* *}$ & $-.03(.01)^{* *}$ & $.15(.07)^{*}$ & $.01(.01)^{*}$ \\
\hline Higher education & $.25(.06)^{* * *}$ & $.04(.01)^{* * *}$ & $.32(.07)^{* * *}$ & $.03(.01)^{* * *}$ \\
\hline Higher religiosity & $.01(.02)$ & $.00(.00)$ & $.00(.02)$ & $.011(.00)$ \\
\hline Rural municipality & $.04(.15)$ & $.01(.02)$ & $-.06(.19)$ & $-.01(.02)$ \\
\hline $\mathrm{N}$ & 3,306 & & 3,560 & \\
\hline$\chi^{2}$ & $(24)=350.35 * * *$ & & $\begin{array}{c}(24)=212.84 * * \\
*\end{array}$ & \\
\hline Pseudo $\mathrm{R}^{2}$ & .0999 & & .0754 & \\
\hline
\end{tabular}

Table 3. Determinants of service responsiveness (contacting a councilor about a personal service or community problem)

\begin{tabular}{|c|c|c|c|c|}
\hline \multirow{3}{*}{ Model } & \multicolumn{2}{|c|}{ Model 3} & \multicolumn{2}{|c|}{ Model 4} \\
\hline & \multicolumn{2}{|c|}{ Contacting councilor (Personal service) } & \multicolumn{2}{|c|}{$\begin{array}{l}\text { Contacting councilor (Community } \\
\text { problem) }\end{array}$} \\
\hline & Logistic coefficients & $\begin{array}{l}\text { Marginal effects } 1 \\
\text { (Predicted } \\
\text { probabilities) }\end{array}$ & $\begin{array}{c}\text { Logistic } \\
\text { coefficients }\end{array}$ & $\begin{array}{c}\text { Marginal effects }{ }^{1} \\
\text { (Predicted } \\
\text { probabilities) }\end{array}$ \\
\hline \multicolumn{5}{|l|}{ Individual-level } \\
\hline Female & $-.59(.14)^{* * *}$ & $-.03(.01)^{* * *}$ & $-.43(.15)^{* *}$ & $-.02(.01)^{* *}$ \\
\hline Higher age & $.01(.01)$ & $.00(.00)$ & $.01(.01)^{\dagger}$ & $.00(.00)^{\dagger}$ \\
\hline Married & $.38(.20)^{\dagger}$ & $.02(.01)^{*}$ & $.53(.22)^{*} .02$ & $.02(.01)^{* *}$ \\
\hline Higher income & $.23(.09)^{* *}$ & $.01(.00)^{* *}$ & $.03(.09)$ & $.00(.00)$ \\
\hline & & 36 & & \\
\hline
\end{tabular}




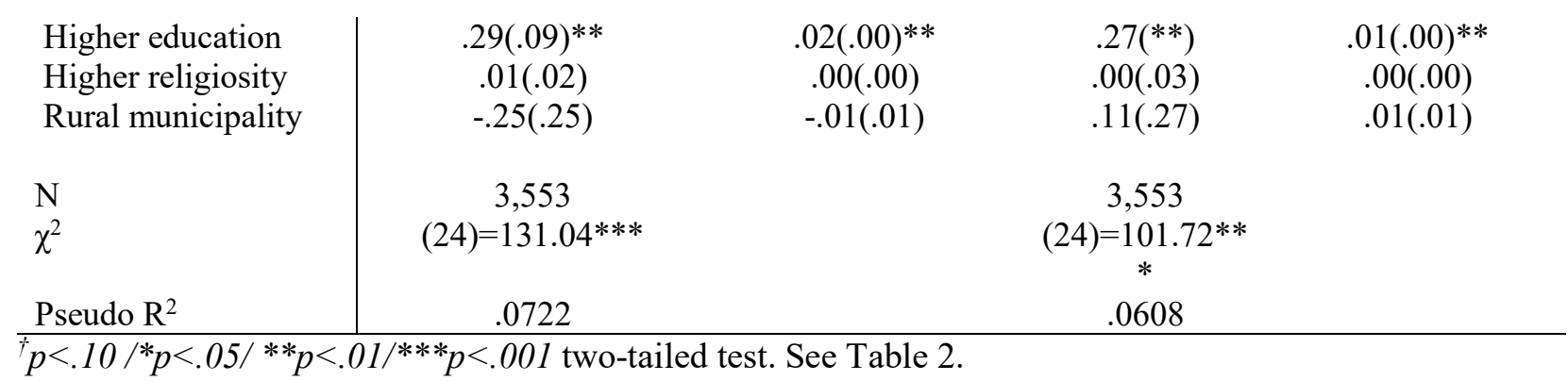

The models also show that women are no more or less likely to contact a female councilor, but they are six percent less likely, all else being equal, to contact a male councilor (Table 4). ${ }^{57}$ While women are as able to contact female councilors, they are less able to contact male councilors than male citizens, in support of $\mathrm{H} 2$. And, males are equally able to contact female councilors as male councilors, in support of H3. This suggests that while electing and appointing women reduces the gender gaps in access to services, it does so by empowering women, not by excluding men.

Table 4. Determinants of service responsiveness (contacting a councilor), by councilor gender

\begin{tabular}{|c|c|c|c|c|}
\hline \multirow{3}{*}{ Model } & \multicolumn{2}{|c|}{ Model 5} & \multicolumn{2}{|c|}{ Model 6} \\
\hline & \multicolumn{2}{|c|}{$\begin{array}{l}\text { Contacting councilor (All contacts), } \\
\text { Female councilor only }\end{array}$} & \multicolumn{2}{|c|}{$\begin{array}{l}\text { Contacting councilor (All contact), } \\
\text { Male councilor only }\end{array}$} \\
\hline & Logistic coefficients & $\begin{array}{l}\text { Marginal effects } 1 \\
\text { (Predicted } \\
\text { probabilities) }\end{array}$ & $\begin{array}{l}\text { Logistic } \\
\text { coefficients }\end{array}$ & $\begin{array}{c}\text { Marginal effects }{ }^{1} \\
\text { (Predicted } \\
\text { probabilities) }\end{array}$ \\
\hline \multicolumn{5}{|l|}{ Individual-level } \\
\hline$\overline{\text { Female }}$ & $.11(.20)$ & $.00(.00)$ & $-.66(.12)^{* * *}$ & $-.06(.01)^{* * *}$ \\
\hline Higher age & $-.02(.01)$ & $-.00(.00)$ & $.01(.00)^{*}$ & $.00(.00)^{*}$ \\
\hline Married & $.58(.40)$ & $.01(.00)^{\dagger}$ & $.55(.17)^{* * *}$ & $.04(.01)^{* * *}$ \\
\hline Higher income & $.07(.20)$ & $.00(.00)$ & $.25(.07)^{* * *}$ & $.02(.01)^{* * *}$ \\
\hline Higher education & $.48(.22)^{*}$ & $.01(.00)^{*}$ & $.37(.08)^{* * *}$ & $.03(.01)^{* * *}$ \\
\hline
\end{tabular}

${ }^{57}$ Fixed effects not included for the female model because it could not be estimated, due to the small n. 


\begin{tabular}{l|cccc} 
Higher religiosity & $-.04(.06)$ & $-.00(.00)$ & $.01(.02)$ & $.00(.00)$ \\
Rural municipality & $-.58(.39)$ & $-.01(.00)^{\dagger}$ & $-.12(.13)$ & $-.01(.01)$ \\
& & & \\
$\mathrm{N}$ & 3,499 & & 3,499 \\
$\chi^{2}$ & $(7)=18.05^{*}$ & $(7)=86.89^{* * *}$ \\
$\mathrm{Pseudo} \mathrm{R}^{2}$ & .0350 & .0367 & \\
${ }^{*} p<.10 /{ }^{*} p<.05 / * * p<.01 / * * * p<.001$ two-tailed test. See Table 2. &
\end{tabular}

In addition, poorer $(\mathrm{p}<.01)$, older $(\mathrm{p}<.05)$, married $(\mathrm{p}<.001)$, and more educated $(\mathrm{p}<.000)$ citizens are more likely to know a councilor personally, while religiosity and rural residence are not significant predictors of knowing a counselor. However, the poor are less able to actually contact local councilors about their concerns. Accordingly to the LGPI, wealthier $(\mathrm{p}<.05)$, older $(p<.05)$, married $(p<.001)$, and more educated $(p<.000)$ citizens are more likely to have contacted a councilor during the last year, to have asked for a personal or community problem, and to have been satisfied with the result. This suggests that Tunisia's highly informal local politics with weak councils benefits not only men, but other advantaged populations as well. The poor may know councilors, but this does not ensure responsiveness to their needs.

\section{Conclusion and Implications}

The results show large gender gaps in knowing and contacting councilors - a thirteen and six percentage point difference, respectively, in bivariate tests. Electing and appointing women to office reduces this gap because women tend to have more females in their networks than do men. Thus, electing women to office is likely to have a minimal impact on men's ability to ask for services. In no municipality were women significantly more likely to have contacted a local councilor than were men, while in six of eighteen municipalities, males were significantly more likely to have done so.

Women in Tunisia were also less likely to contact male councilors, especially when it comes to requests for community resources, which require closer relationships common in 
homosocial networks. Women's marginalization from linkages with male councilors underscores the need for gender quotas for legislative assemblies at national, regional, and local levels in clientelistic settings.

Ultimately, however, the steep gender gaps in knowing and contacting local officials underscores the need for democratic development and decentralization. When local councils are weak, representation will be more personalized and informal, leading to advantages for men, who have more resources and relationships with officials. Tunisia's local councils also appear to be more responsive for more affluent segments of society. Policymakers should strengthen rule of law, bolster local councils' independence and policymaking prerogatives, and improve councilors' capacity to serve the constituency through funding for local offices and staff. By strengthening local councils and decreasing clientelism, all groups, including women, will have more equal access to elected and appointed officials.

Women receive comparatively fewer requests for help than do male councilors, and requests to females are rarely for public works like water or roads. Instead, female councilors most often receive requests for education, telephone, and government documents and licenses. Some work frames gender differences in requests as reflecting different policy preferences. ${ }^{58} \mathrm{But}$, gendered power structures, including male dominance in some professions and greater clout with the central government, could also produce differences in what men and women ask for. As a result, male citizens are also more likely than females to be able to request community resources from male councilors. This is troubling and suggests that quotas do not automatically alter gendered power structures or lead to gender parity in representation in a clientelistic system.

\footnotetext{
${ }^{58}$ Chattopadhyay and Duflo, "Women as Policy Makers."
} 
The LGPI also shows large sub-national variation in women's access to services as well as overall service provision, that must be addressed in further research. For instance, the proportion of women who have asked for help from any councilor ranges from 0.9 percent in Jebel-Jelloud (governorate of Tunis) to 26.7 percent in Moknine (governorate of Monastir) (Table 1). As an urban, affluent district in which women are expected to have limited contact with local councilors, Tunis's large gender gap in access to local councilors is surprising. Explaining variation across localities is a puzzle that merits investigation.

Data from nationally-representative surveys in Algeria, Morocco, and Tunisia also find similar gender gaps in access to help from local councilors, suggesting that the results are likely to generalize outside Tunisia (Appendix 1). The nationally representative surveys also suggest that gender gaps at the local level are at least as large as gaps for access to parliamentarians. This runs contrary to assumptions that females might have more trouble contacting national than local elites. But it also underscores the need to understand how electing women at different levels of government shapes service, allocation, and policy responsiveness.

Given that Tunisia is the most gender equal society in the MENA region, that gender gaps in access to services exist also suggests that gaps are likely to be much larger in other countries which do not have the same history of state feminism experienced by Tunisia. At the same time, the election of a large number of women in Tunisia in the most recent municipal elections in 2018 — forty-seven percent—raises questions about how increasing descriptive representation shapes substantive representation of women.

Women's presence may also have symbolic effects, particularly as they are present in their municipalities and respond to citizens' requests for services and club goods. Symbolic effects can take the form of decreasing biases against females at the polls and changing social 
attitudes about women as political leaders, or broader impacts such as encouraging women to vote, pursue education, or take on leadership roles. ${ }^{59}$ As women become engaged in local government and provide services to their constituents, public biases against females as local councilors may also decrease. Yet, more research needs to be done to examine these effects. The results extend existing work on gender and governance by examining service and allocation effects among local councilors and underscoring the findings of previous studies that women are less likely to demand clientelistic services because they are more marginalized from networks with political elites. While gender gaps in access to services exist, another perhaps more serious problem is that women are less able to ask for help with community problems when few females serve in local councils.

The findings further underscore the importance of strong quotas, such as those implemented in Tunisia for its 2018 municipal elections, as a means of achieving gender parity at all levels of government. Quotas ensuring at least parity in elected government are needed, but similar measures in other sectors in the public and private sector are also critical for addressing underlying gendered power structures.

Moreover, decentralization is needed to ensure greater regional equity in state resource distribution and improve the transparency and effectiveness of service provision. Ultimately, continued democratic development and decentralization are crucial in Tunisia in order to strengthen the prerogatives of local councils and decrease the extent to which informality

${ }^{59}$ Beaman et al., "Powerful Women"; Benstead, Jamal, and Lust, "Is It Gender, Religiosity or Both?" 
mediates the provision of services and community goods in order to ensure gender equity in local representation. 


\section{Appendix 1: Interactions with Local Officials in Morocco and Algeria}

According to nationally representative surveys of 800 Moroccans and 800 Algerians, ${ }^{60}$ men are more likely than women in Morocco and Algeria to say that they would seek help from local or regional assembly members for government services or jobs, consistently with $\mathrm{H} 1$. As shown in Figure A1, women in Morocco state more often than men that they would contact a local or regional councilor for help with government services - fifty-six percent of men and sixty-six percent of women - a reverse gap of ten percent. However, men were more likely to state that they would contact a local official first about government services (nine percent of men compared to five percent of women) and that it would be most effective (twelve percent of men compared to nine percent of women).

In Algeria, seventy-six percent of men and seventy-one percent of women would contact a local or regional councilor for help with government services. Six percent of men and one percent of women would do this first, while nine percent of men and eight percent of women believe contacting a local councilor would be the most effective. However, when asked about getting a job, women in Algeria were slightly more likely than men to state that they would contact a local or regional official, that they would try it first, or that they believe it would be most effective. These findings generally support $\mathrm{H} 1$ and provide compelling, though not surprising, evidence of gender gaps in access to local and regional councilors in Morocco and Algeria. That reverse gender gaps exist in Algeria for seeking a government job suggests that inequalities in service provision depend on the type of service or individualized benefit sought.

${ }^{60}$ Lindsay J. Benstead and Ellen Lust, “Constituent Survey,” 2007-2008, accessed November 28, 2018. 
Figure A1. Percentage willing to contact local and regional officials in Morocco and Algeria

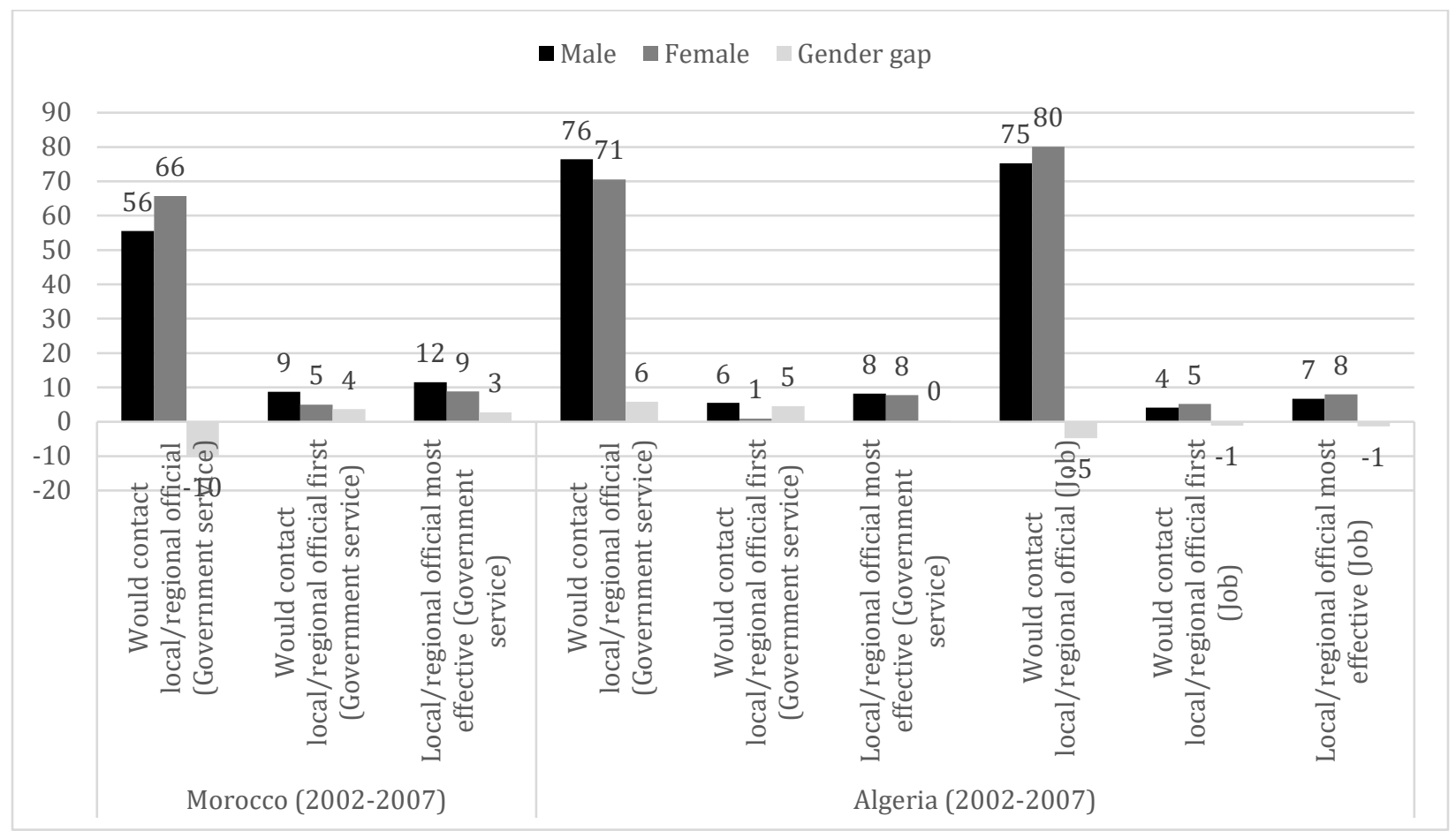

Source: Constituent Survey (2007-2008). Question wording. "If you need to deal with the government, such as to gain access to government housing programs, resolve a problem with the health or education system, dispute taxes, or apply for licenses, would you: Ask a local government authority such as the APC or the APW to mediate? Which would you be most likely to try first? Which would probably be the most effective?" 


\section{Appendix 2: Question Wording and Descriptive Statistics}

\section{Table A2.1. Question Wording for Interactions with Local Councilors}

\begin{tabular}{|c|c|c|c|}
\hline 1. Yes & 2. No (skip to 405) & $\begin{array}{l}\text { 96. Don't know } \\
\text { (skip to } 405 \text { ) }\end{array}$ & $\begin{array}{l}\text { 97. Refuse to answer (skip } \\
\text { to } 405 \text { ) }\end{array}$ \\
\hline \multicolumn{4}{|c|}{$\begin{array}{l}\text { 404.1. The last time you contacted a member of the local council, was it about a personal or } \\
\text { community problem? }\end{array}$} \\
\hline 1. Personal & 2. community problem & 96. Don't know & 97. Refuse to answer \\
\hline
\end{tabular}

\begin{tabular}{|c|c|c|}
\hline $\begin{array}{l}404.2 \text { (The last time y } \\
\text { address? [Read out ca }\end{array}$ & $\begin{array}{l}\text { ed a member of the local } \\
\text { to } 6 . \text { More than one answ }\end{array}$ & $\begin{array}{l}\text { il) what type of issu } \\
\text { sible.] }\end{array}$ \\
\hline 1. Employment & $\begin{array}{l}\text { 2. License or government } \\
\text { document }\end{array}$ & 3. Electricity \\
\hline 4. Water & 5. Telephone or Internet & 6. Healthcare \\
\hline 7. Education & 8. Housing & 9. Roads \\
\hline 10. Transportation & 9. Other (specify): & 96. Don’t know \\
\hline 97. Refuse to answer & 98. Doesn't apply & \\
\hline $\begin{array}{l}404.3 \text { (The last time y } \\
\text { female? }\end{array}$ & ted an official) was the me & you contacted male or \\
\hline 1. Male & 2. Female & 97. Refuse to answer \\
\hline
\end{tabular}

404.4 (The last time you contacted an official), were you very satisfied, somewhat satisfied, somewhat dissatisfied, or very dissatisfied with the response?

\begin{tabular}{|l|l|l|l|}
\hline 1. Very satisfied & $\begin{array}{l}\text { 2. Somewhat } \\
\text { satisfied }\end{array}$ & $\begin{array}{l}\text { 3. Somewhat } \\
\text { dissatisfied }\end{array}$ & 4. Very dissatisfied \\
\hline 96. Don't know & 97. Refuse to answer & 98. Doesn't apply & \\
\hline
\end{tabular}

405. If you had a personal problem in the future that one of the members of the local council could do something about, do you think he or she would be very helpful, somewhat helpful, or not very helpful?

\begin{tabular}{|l|l|l|}
\hline 1. Very helpful & 2. Somewhat helpful & 3. Not very helpful \\
\hline 96. Don't know & 97. Refuse to answer & \\
\hline
\end{tabular}

405.1 Do you personally know any local council members in this municipality?

\begin{tabular}{|l|l|l|l}
\hline 1. Yes & 2. No & 96. Don't know & 97. Refuse to answer \\
\hline
\end{tabular}

Source: LGPI. 


\section{Table A2.2. Question Wording for Independent Variables in Table 2 and 3}

Female: Male (48.9\%), Female (51.1\%). Mean=.51, S.d.=.50.

Higher age: Age in years (Range $=18-102$ years). Mean=43.62, S.d. $=16.61$.

Married: Never married (27.80\%), Married, engaged, widowed, separated, or divorced (72.20\%).

Mean $=.72$, S.d. $=.45$

Higher income: 1 (18.07\%), 2 (49.00\%), 3 (23.93\%), 4 (9.01\%). Mean=2.24, S.d.=.85.

Higher education: 1 (8.94\%), 2 (19.07\%), 3 (36.89\%), 4 (35.10\%). Mean=2.98, S.d.=.95.

Higher religiosity: Range (1-9). "On a scale of 1-5 which number better represents you if 5 means a person who goes to houses of worship daily, takes religious lessons, listens to religious programs and reads religious books, while the number 1 means a person who rarely does these things?" Mean=4.51, S.d.=2.80.

Rural: Rural (28.0\%), Urban (72\%). Census designation. Mean=.28, S.d. $=.45$.

Source: LGPI. 